\title{
Letters of Childhood and Youth: Characteristics and Theory
}

\author{
Gassim H. Dohal \\ Independent Researcher, Gizan, Saudi Arabia
}

\begin{abstract}
The letter is a cultural and social phenomenon that is used to defy space and time that separate friends. Today, we use telephone, e-mail, fax, and many other means in order to communicate with our friends. But before the electronic age, letters were the main medium of communication for friends who were separated for whatever reasons. While being used as a way of communication in the past, today we read letters as texts for their cultural, historical, literary, and social values. This way of communication requires some attention for it will give us as readers a picture of social and cultural life of the period in question. Also it will provide researchers a solid background to explore the beginning of those great writers.
\end{abstract}

Index Terms-letters, childhood, communication, cultural, postmodern

\section{INTRODUCTION}

Letters of childhood and youth have some general characteristics. These characteristics might be found in other types of letters, but they are clearly noticeable in children's letters. One of these characteristics is spontaneity. The spontaneity in children's letters is due to the freedom that children find in the letterform, and the innocence they tend naturally to have. Their innocence leads them to write what they have in mind. Thus, writing letters at early age tells us about the development of children's literacy. We find grammatical and spelling mistakes. These mistakes show us what we are to expect from our children. If these and the like characteristics are clearly noticeable in children's writing to each other, then is it going to be the same characteristics when a child writes to an adult? And is there any difference when an adult writes a letter to a child? I will try to answer such questions, discuss the main characteristics of letters of childhood and youth, and theorize these letters in the light of postmodernism.

Decker (1998) argues, "to readers outside the epistolary exchange it [letter] becomes a document to be read for its various levels of biographical, historical, and literary interest" (p. 24-5). But because there is a great number of letters, we have to classify them. However, there is no way to classify letters on the basis of forms or structures because letters do not have specific forms. They might be classified on the basis of either the correspondents' type or the content of letters.

Writing letters is a genre that includes sub-genres, such as letters of childhood and youth, letters of business, letters of daily life and work, etc. Each sub-genre has its message, subject, and audience (reader). However, these sub-genres might intersect with each other. For example, we may find a letter of childhood with a daily life subject. What makes us determine, for example, that a letter is one of childhood and youth is that it is sent to a child or youth and/or written by a child or a youth. Selected letters by Emily Dickinson, John Keats, Margaret Fuller, Margaret M. Davidson, Susan Hale, and Celia Thaxter will be the focus of my discussion. The idea behind choosing this type of letters is that they reflect and represent the early beginning of a writer in the realm of literary writing. They show the importance of childhood in the life of a writer. In addition, the letters written by adult people, in case of Keats and Thaxter, to children show how they were aware of the world of childhood, and accordingly managed to deal with children's interests and tendencies.

\section{DISCUSSION}

The letter, a social contract of sorts, represents in its seemingly happy message the acceptance of responsibility and obligation between two human beings and with a larger society. It depends on reticence. Through what it withholds it creates an idealized image of a woman's life. It is a fiction. (Beauchamp, 1985, p. 40)

Usually subjects of children's interests discussed in letters of childhood are about school, learning, friends, homesickness, health, and things of mutual interest. When a child is separated from his/her friend(s), the first thing s/he thinks about is how to keep in touch with friends. Letters in general including those of children and youth are written to bridge the geographic spaces that separate people prior to the electronic age. Indeed, letters give friends a chance to know what is going on with the sender. Though the reason of probably all letters is the separation of friends, yet the idea of separation is embodied in the letters of children and youth in a clear and frank way. Going to or leaving a school caused separating Emily Dickinson from her brother and her friend Abiah Root. Austin was sent away to school. Emily herself left school many times for reasons of health. Some of her friends were girls sent to Amherst from other towns, particularly Jane Humphery and Abiah Root. Emily's earliest letters were written to her brother and to these two schoolgirls. Though she wrote these letters while being a child, yet these early letters showed how her mind and ability 
to write were developing rapidly. Her letters even in early stage serve as experiments in literary style through which she can develop her literary status later in poems and letters. In her early letters, she finds a way to express her opinions to others. At the same time, she finds no constraints in the letterform that limit her ability of writing. She can write whatever she wants in whatever expressive way she thinks.

Going to school also gives Margaret Fuller a chance to write to her father. She writes to him about school and her teachers. Also, Susan Hale (1918) writes about school, "I am now fairly launched on the sea of education, or school" (p. 4). Such a statement shows us the literary ability that Hale as a child has. A reader will appreciate the use of "sea" in the previous sentence. It is right that education is some sort of sea with different depths, levels, kinds of valuable things, etc. Even John Keats wrote to his sister Fanny recommending Miss Taylor's essays in Rhyme for her to read. Hence, we see that the frequent subject of this genre is about learning and teaching --things relevant to children's interests. It is rarely to find a child's letter without reference to school, and learning. Since children are connected to some extent with school, then generally what separates friendly children is either leaving school or going to school. This separation causes the loss of the addressee.

The loss of a friend is a powerful force that pushes a correspondent to send a letter. The concept of loss develops in Dickinson's mind to become a complete and never-to-meet-again loss, i. e. death. Death becomes her main poetic theme. Losing a friend was a great loss to her. She writes to her brother, "We miss you very much indeed you cannot think how odd it seems without you there was always such a Hurrah wherever you was I miss My bedfellow very much" (Dickinson, 1958, L(etter) 1). She puts much emphasis on losing a relative or a friend. In her letter to Jane Humphery, she writes, "I miss you more and more every day, in my study in play at home indeed everywhere I miss my beloved Jane" (Dickinson, 1958, L 3). Also, her correspondence with Abiah shows how she misses her. Fuller (1988) expresses her loss of her father in counting the months: "And it is January, my dear sir, How the winter has flown. You have been gone two months." These are just examples. Indeed, the loss of a friend is what causes others to write in order to create a sort of epistolary dialogue with their addressees. Children who write letters realize such a loss because they are not used to such a loss of friends.

Space and time separate people from each other. Hence, they miss each other. Nowadays, we use telephone, e-mail and fax in order to overcome and defy space and time that separate us from our friends. But in the $19^{\text {th }} \mathrm{c}$., letters were the medium of communication. The writers were aware of the geographical spaces that separate them from their friends and the long time their letters need to reach their readers. Their awareness is represented in the words that were used frequently in their letters, such as "write soon," "now," "here," "there," etc. The awareness of separation is accompanied by a sense of innocence in children's letters. A reader finds a lot of references to place and time in children's letters. Children use their correspondence in order to narrow the distance that is caused by geographical space that separates them from their friends.

Children are able to create an epistolary correspondence that keeps them in touch with their friends. Letters become a way of dialogue between correspondents. They request information and news, tell and comment on some other information. But we may need to know the other side of each correspondence in order to put each letter in its context. Sometimes a letter is an answer of a request or a question posed by the other side of the correspondence. There are other possibilities for writing a letter. This is why we describe this genre as multiauthorial, in the sense; the text is not a writerly text where one author controls everything. Children's letters contain a lot of information, and a reader may get lost if s/he has no clue to follow in both correspondents' letters. In other words, letters as genre are readerly texts. What the sender does is what s/he expects the addressee to share. Hence, codes might be used. Questions and requests are to be answered by the addressee. These ideas work with reader response theory where the reader is the one who can determine the meaning of the text. As an example, let us have the following excerpt where Dickinson (1958) writes to Abiah, a friend of the same age,

I am not unconcerned Dear A. upon the all important subject, to which you have so frequently \& so affectionately called my attention in your letters. But I feel that I have not yet made my peace with God. I am still a s(tran)ger --to the delightful emotions which fill your heart. [L(etter) 13]

In the above quotation, Dickinson writes as if she were talking with Abiah telling her own standpoint towards the issue of belief in God. She uses "you" and "your" as if she were talking to Abiah in person. On the other hand, she affirms her subjectivity through using the pronoun "I" four times and the pronoun "my" twice in the previous short excerpt. This emphasis on her subjectivity shows how a young girl insists on conveying her opinion to others, particularly when they are of the same age. One finds it easier to express him/herself freely and easily when s/he talks to someone of the same age. On the other hand, if we look at Fuller's letter to her father, we find that she affirms her opinion by using the first-person pronoun many times. She writes, "I am sorry my dear sir you write to me seldom. Has your affection decreased? I fear it has; I have often pained you but I hope you still love me . ..” (Fuller, 1988). These are examples. Indeed, letters of children are full of singular first-person pronoun. The best way to express one's own opinion is to use this pronoun.

Children create their epistolary dialogue in order to express themselves to other friends. To create this self-expressive dialogue, a writer keeps reminding the addressee to write back as soon as s/he can. The addresser may pose some questions, e.g. Dickinson (1958) writes to Jane, "How do you get along in Latin" (L 3). This question shows us how children are curious about learning different skills. In another occasion, she asks her brother, "Do you know of any 
nation about to besiege South Hadley" (L 16)? Such a question pops up not out of ignorance but out of trying to engage her addressee in an epistolary dialogue. It is a childlike way to get others involved in what is going on. At that time both correspondents know what is going on between them, but we, as readers of another era, need margins and notes in order to understand some phrases and ideas. For the previous quotation, we need notes about the war and the besiege she refers to in her letter. When names are mentioned in a letter, we need notes to know these people. For example, in her 1848 letter to Alexander Hale, Susan refers to Fullum, but she did not tell that he was a servant. Thus, we need to put these letters in their cultural, historical, and social context in order to decode them because these letters are read now not for the purpose of communication but for their aesthetic and literary values.

In the past, these letters were used mainly for the purpose of communication between a writer and a particular audience (reader). For example, Davidson (1851) tries to create a way of epistolary communication when she writes to a female friend, "I will endeavour to answer your question about Mrs. Hemans" (p. 63). Keats (1925), on the other hand, asks his sister, "Do write me a Letter directed to Inverness. Scotland." Thaxter (1895) also engages her reader in a semi-dialogue through posing questions such as: "Wasn't that cruel? Think of little Anson exposed to such a dreadful storm!"' (p. 18). Raising questions and requesting a lot of information at the same time are a childlike issue because it is the child who tries to explore and learn about everything at once. The adult, by contrast, asks questions but within his/her limits and focus. In other words, the child is not aware of his/her shortcomings as far as information is concerned. So s/he asks about and for whatever s/he wants to know and to have. And this is what is found in children's letters. I think that both Keats and Thaxter are successful when they put in their letters what children wanted to hear; both relate narratives and pose questions in order to engage their addressees in an epistolary dialogue. This is what a reader expects when an adult writes a letter to a child.

A child needs to hear some stories mixed with questions to get him/her engaged in the narrative in question. Thaxter tells a narrative of a family's disaster. Keats relates his journeys to Liverpool and Oxford. These writers have put in their letters to children what children as readers expect to find in these letters. Adult writers usually think in their audience. The audience affects the content and subject choice of the letter. A letter reflects a writer's position and opinions and at the same time should be of great interest and amusement to the reader. This is what happens when Keats writes a letter to Fanny. His letter reflects his interest in poetry for he inserts a ballad and a song in his letter. At the same time, he tries to amuse Fanny through relating his journey to her and filling his letter with a variety of genres: a narrative, a ballad, and a song. Decker (1998) quotes from Adams, "They [letters] are written only on the chance that they may give you [as an original reader] half an hour's amusement” (p. 18). As I mentioned above, Keats (1925) in the 1817 letter wants to "adapt my Scribblings to your pleasure." To children, stories are a kind of amusement. Keats uses the method of narrative to tell his sister his story. Thaxter also relates a narrative of a travelling family in a letter to Nanny Hoxie. A narrative usually contains a plot, characters, a beginning, middle, and an end. This is a good teaching method to present other genres to children. Adult writers might also suggest things in their letters to children like reading a book or doing something. For example, Keats recommends reading a rhyme book to his sister.

By comparison, when a child writes a letter to an adult, the child tends to comfort the adult and tells him/her that everything is going on well. Also the letter usually reflects the strength of relation between the correspondents. Margaret Fuller writes to her father about what has happened to her. Her letters show her strong relation with her father; many times she calls him, "my dear father." Her relation with her father is strong enough that she dares to ask him to "bring me home a complete case of jewels or something equal to it ..." and to tell him her inner feeling, "I am sorry my dear sir you write to me so seldom. Has your affection decreased?" (Fuller, 1988).

Though the children use the letters as a medium of communication to express themselves and convey their opinions to their addressees, yet these children become aware of the limits and shortcomings of this way of communication. So we see them insist in their letters on meeting their addressees and exchanging news in person. Insisting on meeting is a clear characteristic in children's letters. Dickinson (1958) writes to Jane, "I want to see you very much for I have got a great deal to tell you about school matters" (L 3). When one reads such a sentence, s/he feels that neither paper nor ink can fit what she wants to talk about. Fuller (1988) writes, "I have a thousand things to say but neither time or paper to say them in." However, Davidson (1851) realizes the limits of using letters as a communicative way: "You say the effects of conveying feelings from the heart and recording them upon papers seems to deprive them of half this warmth and ardour" (p. 63). Thus, she pleads, "Oh how I long to have you here and tell you all the little things in person" (p. 85). Meeting in person is something great for children because they get used to it. On the contrary, adults get used to separation and travel. Hence, their insistence on meeting is less than that of children.

I talked about separation of a friend and the need of meeting but what about leaving home where one has lived his/her early life? When a child goes for the first time out of home, the main thing to think of will become home. For children, home becomes a symbol of the early life, of the past to which the child belongs. Dickinson (1958) writes to Abiah, "I was very homesick for a few days \& it seems to me I could not live here" (L 18). Davidson (1851) does "long to revisit the home of my infancy, and the friends of my earliest remembrance" (p. 64), and on the same page and in the same letter, she adds, "yet with all these advantages, it [New York] can never possess half the charms of my dear old home." For her, home could not be compared with any other place. It is the home that does "possess" "the charms." Indeed, letters enhance children's ability to express themselves in writing towards issues in question. Due to their innocent childhood, children tend to feel free to express themselves and say whatever they want to say. There is no 
doubt that any writer will embody ever unconsciously his/her inner feelings and attitudes towards things of personal interests, yet children write without any reservations. At the early age, one writes spontaneously and feels free from any barriers and restrictions. But whenever one gets old, s/he starts to pay attention to what is written. Thus, a part of truth may be disclosed out of reticence. Following the children's literary development helps us to understand their writings when they get older because at the early stage, they write without reservation and reticence. Indeed, a lot of information is usually found in one's early writings.

Letters of children are informative. A lot of information is put on the page and sometimes in the same paragraph. There are a lot of questions posed in letters. Having fragments of ideas, information, and questions --and in some cases drawings, as it is the case with Hale's letters-- put together raises the issue of theorizing such letters in the light of postmodern theory. For example, Dickinson (1958) writes to her brother,

We are all very well and hope you are the same-- we have very pleasant weather now Mr Whipple has come and we expect Miss Humphrey tomorrow -Aunt Montague--has been saying you would cry before the week was out Cousin Zebina had a fit the other day and bit his tongue into --as you say it is a rainy

day ... (L 1).

Dickinson (1958) here writes whatever idea comes through her mind. It is the way children think and use to do. At a sudden, changes and mixing ideas may happen. The younger the child is the better what comes in mind is expressed spontaneously and freely. At ten, Fuller (1988) writes to her father,

You will let me read Zeluco? will you not and no conditions. Have you been to the theatre this winter? Have they any oratorios at Washington? --I am writing a new tale called the young satirist. You must expect the remainder of this page to be filled with a series of unconnected intelligence.

A lot of information and ideas are put together. We do not expect this way of writing from an adult. However, the addressees are supposed to be familiar with shifting from one topic into another as long as the sender is a child. What is written does usually have something to do with the reader's interests and expectations. Dickinson (1958) writes to Austin, "the chicken grow very fast" (L 1), and she tells Abiah about "how I have spent the time here [at school]" (L 13).

Children's letters tell us not only about what is going on between the correspondents but also about how they start writing. For example, Dickinson's writings even in the early stages promise a great writer. There is a sense of fluent, simple and expressive style in her early letters. See how she expresses her loss of Abiah in a poetic way,

Slowly, very slowly, I came to the conclusion that you had forgotten me, \& I tried hard to forget you, but your image still haunts me, and tantalizes me with fond recollections . . . tell me what had sealed your lips toward me? Did my letter never reach you, or did you coolly decide to love me, \& write to me no more? . . but if you dont want to be my friend any longer, say so, \& I'll try once more to blot you from my memory. (Dickinson, 1958, L 26)

She uses "slowly" as if there is a movement, then "image" and "haunts" as if the situation is not real; there is some sort of apparition. She personifies the past memory as something tantalizing. Creating such an image in her writing reflects her early literary tendency. She does not want this image. She wants a real thing: "I long to see you [Abiah] once more, to clasp you in my arms \& to tell you of many things which have transpired since we parted" (L 13). Above all, Dickinson tries to find an excuse for Abiah as a trial to convince her to write back. Dickinson is creating a dialogue with her own conscience; she is talking on behalf of Abiah as if Abiah had forgotten to keep the contact with her. Everything goes through her imagination. It is through imagination that a writer can create a literary work.

In addition to reflecting an earlier literary development, letter writing tells us of the writer's psychological side. Understanding the writer's psychology at early age will give us as readers a chance to know the factors that affect his/her life and that have something to do with his/her future literary themes and interests. For example, Dickinson's writings show how she loves solitude. She writes to her brother, "Almost all the girls went \& I enjoyed the solitude finely" (Dickinson, 1958, L 16). Davidson (1851), by contrast, is social; she hates to be alone: "I will only say, one does not like to be alone" (p. 66). But it is her weak lungs that deny her "the free enjoyment of nature" (p. 84). Thus, it is through the surviving letters that we learn about writers' tendencies that affect their literary future.

Besides learning about a writer's interest and psychology from his/her early writings, children's letters are taken as autobiographical documents in the sense that they describe what has happened to the writers in each situation. Hale (1918) writes, "I began this afternoon to take drawing lessons" (p. 1). Fuller (1988) writes, "I attend a school which is kept by Aunt Abigail." Of course, we learn when Hale starts drawing lessons, and the person who taught Fuller from the date of the letters that include these quotations. Having autobiographies in the form of letters gives us a chance to study the psychological and social background of the writer's era. This kind of study helps us to reconstruct the past by looking at each writer's writings and trying to theorize them. For example, if the writer is a female, then we can look at her early writings from a feminist point of view and try to learn how she resists the male domination from the very beginning.

\section{CONCLUSION}

In a nutshell, we read letters of childhood and youth as printed texts. Hence, reading these letters requires, as Decker (1998) points out, "acts of imagination and empathy" (p. 4). He adds that these letters reveal and express "a sense of 
space and time different from our own" (p. 4). As an unintended audience, we are to place these letters in their context in order to understand and explore them. We have to realize that these letters are multiauthorial. Even when correspondents are children, there are many phrases and words that need some margins and notes in order to be understood by the contemporary reader. These letters are different in their cultural, historical, and social context from ours.

Letters of childhood and youth represent a sub-genre that has its clearly noticeable characteristics. Such a sub-genre is related to children's interests and tendencies. It deals with childlike subjects such as school, learning, homesickness, health, etc. In children's letters, one finds spontaneity that is clearly noticed. Children become free to express themselves in whatever way they like because there is no specific letter form that limits and restraints the way of their writings. Their letters reflect their opinions, show their literary development, and help us to understand the writers and study them culturally, historically, and socially. However, we find in children's letters a lot of questions and a variety of information. Since each letter contains fragments of ideas, information, different genres, etc., then we can look at these letters from a postmodern point of view. Children can express themselves in letters because there are no boundaries that limit their ability of writing.

\section{REFERENCES}

[1] Beauchamp, V. W. (1985). "Letters and Diaries: The Persona and the Real Woman.” Women's Personal Narratives: Essays in Criticism and Pedagogy. Ed. Leonore Hoffman and Margo Culley. New York: The Modern Language Association of America, pp. 40-47.

[2] Davidson, M. M. (1851). "To a Young Female Friend." 26 February 1837. Biography and Poetical Remains of the Late Margaret Miller Davidson. Ed. Washington Irving. New York: Clark, Austin \& Co., pp. 62-63.

[3] Davidson, M. M. (1851). "To the Same." 2 April 1837. Biography and Poetical Remains of the Late Margaret Miller Davidson. Ed. Washington Irving. New York: Clark, Austin \& Co., pp. 63-65.

[4] Davidson, M. M. (1851). "To a Young Friend." 26 March 1838. Biography and Poetical Remains of the Late Margaret Miller Davidson. Ed. Washington Irving. New York: Clark, Austin \& Co., pp. 84-85.

[5] Davidson, M. M. (1851). (A Letter without Salutation). Dated June 1837. Biography and Poetical Remains of the Late Margaret Miller Davidson. Ed. Washington Irving. New York: Clark, Austin \& Co., pp. 65-66.

[6] Decker, W. M. (1998). Epistolary Practices: Letter Writing in America before Telecommunications. Chapel Hill: U. of North Carolina P., 1998.

[7] Dickinson, E. (1958). “To Abiah Root.” 8 September 1846. Letter 13 of Emily Dickinsom: Selected Letters. Ed. Thomas H. Johnson. Cambridge: Harvard UP, pp. 3-4.

[8] Dickinson, E. (1958). "To Abiah Root." 6 November 1847. Letter 18 of Emily Dickinson: Selected Letters. Ed. Thomas H. Johnson. Cambridge: Harvard UP, pp. 17-18.

[9] Dickinson, E. (1958). "To Abiah Root." 29 October 1848. Letter 26 of Emily Dickinson: Selected Letters. Ed. Thomas H. Johnson. Cambridge: Harvard UP, pp. 25-26.

[10] Dickinson, E. (1958). "To Austin Dickinson." 18 April 1842. Letter 1 of Emily Dickinson: Selected Letters. Ed. Thomas H. Johnson. Cambridge: Harvard UP, pp. 3-4.

[11] Dickinson, E. (1958). "To Austin Dickinson." 21 October 1847. Letter 16 of Emily Dickinson: Selected Letters. Ed. Thomas H. Johnson. Cambridge: Harvard UP, pp. 15-17.

[12] Dickinson, E. (1958). "To Jane Humphrey." 12 May 1842. Letter 3 of Emily Dickinson: Selected Letters. Ed. Thomas H. Johnson. Cambridge: Harvard UP, pp. 4-5.

[13] Fuller, M. (1988). “To Her Father.” 16 January 1820. Letters of Margaret Fuller. NY: Cornell UP.

[14] Hale, S. (1918). "To Alexander Hale." 1 November 1848. Letters of Susan Hale. Ed. Caroline P. Atkinson. Boston: Marshall Jones Company, pp. 1-3.

[15] Hale, S. (1918). "To Alexander Hale." 14 October 1849. Letters of Susan Hale. Ed. Caroline P. Atkinson. Boston: Marshall Jones Company, pp. 4-5.

[16] Johnson, T. H. (Ed). (1958). Emily Dickinson: Selected Letters. Cambridge: Harvard UP.

[17] Keats, J. (1925). "To Fanny Keats." 2-5 July 1818. Letters of John Keats to His Family and Friends. Ed. Sidney Colvin. London: Macmillan and Co.

[18] Thaxter, C. (1895). “To Nanny Hoxie.” 30 Jan. 1859. Letters of Celia Thaxter. Ed. Her Friends A. F. and R. L. NY: Houghton Mifflin Co., p. 14.

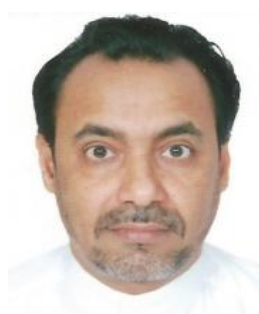

Gassim H. Dohal is an instructor of English from Gizan, Saudi Arabia. He holds a Ph. D. in English Literature. He has contributed research papers and articles in different academic journals. His works appeared in journals like Agathos journal, The IUP Journal of English Studies, Annals of the Faculty of Arts of Egypt: Ain Shams Univ., International Journal of Comparative Literature and Translation Studies (IJCLTS), and many others.

Email: dr_waitme@hotmail.com 